\title{
BERSIHAN JALAN NAFAS TIDAK EFEKTIF DENGAN MENGGUNAKAN LARUTAN JERUK NIPIS DAN MADU DI KELURAHAN SUKABUMI BANDAR LAMPUNG
}

DOI: https://doi.org/10.33024/jkpm.v4i5.2846

\author{
Nocivera Indriany ${ }^{1}$, Eka Trismiyana ${ }^{2 *}$ \\ ${ }^{1}$ Mahasiswa Universitas Malahayati \\ ${ }^{2}$ Dosen Program Studi Keperawatan Universitas Malahayati
}

Disubmit: 12 Juni 2020

Diterima: 03 Mei 2021

Diterbitkan: 03 Oktober 2021

Email Korespondensi: nocifera68@gmail.com

\begin{abstract}
ABSTRAK
Infeksi pernafasan merupakan penyakit akut yang paling banyak terjadi pada anak-anak, Penyakit ISPA sering terjadi pada anak Balita, karena sistem pertahanan tubuh anak masih rendah. Kejadian batuk pilek pada balita di Indonesia diperkirakan 3 sampai 6 kali pertahun, yang berarti seorang balita. Tujuan deskripsi hasil asuhan keperawatan komprehensif pada keluarga Tn.S dan Tn.I dengan masalah keperawatan bersihan jalan nafas tidak efektif dengan menggunakan larutan jeruk nipis dan madu di kelurahan Sukabumi Bandar Lampung. Dianjurkan memberi obat batuk yang aman yaitu ramuan tradisional yaitu jeruk nipis $1 / 2$ sendok teh dicampur dengan Madu atau Madu $1 / 2$ sendok teh, diberikan tiga kali sehari. Air perasan jeruk nipis dicampur dengan Madu manis juga menjadi pilihan masyarakat dalam meredakan batuk dan melegakan tenggorokan. Pilihan ini juga telah tercantum di dalam MTBS (Manajemen Terpadu Balita Sakit) dalam mengajari ibu cara mengobati infeksi lokal di rumah. Caranya adalah dengan memotong satu buah jeruk nipis, peras airnya, taruh dalam gelas/cangkir. Tambahkan Madu manis, aduk. Takaran minum untuk anak, 3 kali sendok teh per hari. Cara lain, Madu manis bisa digantikan dengan Madu murni. Keluarga dengan masalah ISPA teratasi dengan Jaruk nipis dan madu dengan hasil efektif pada kedua pasien hanya saja kadar penurunan penumpukan secret, penurunan batuk dan waktu tidur lebih baik.
\end{abstract}

Kata kunci : ISPA, Kecap, madu

\section{ABSTRACT}

Respiratory infection is an acute disease that most commonly occurs in children, ARI often occurs in children under five, because the child's immune system is still low. The average cold cough in toddlers in Indonesia is estimated to be 3 to 6 times per year, which means a toddler. Purpose description of the results of comprehensive nursing care in the family of Mr.S and Mr.I with nursing problems cleansing the airway not effective by using lime and honey solution in Sukabumi Village, Bandar Lampung in 2020. It is recommended to provide cough medicines that are safe to use traditional $1 / 2$ teaspoon mixed with Honey or Honey $1 / 2$ teaspoon, given three times a day. Orange juice mixed with sweet honey is also a choice of people in relieving coughs and soothing throat. This option has also 
been verified in MTBS (Integrated Management of Sick Toddler) in teaching mothers how to treat local infections at home. The trick is to cut one lime, squeeze the water, put it in a glass / cup. Add sweet honey, stir. Drinking dose for children, 3 times a teaspoon per day. Alternatively, sweet honey can be replaced with pure honey. Families with ARI problems resolved with lime and honey with effective results in both patients except secret buildup levels, decreased coughing and better sleep time.

Keywords: ISPA, sauce, honey

\section{PENDAHULUAN}

Infeksi pernafasan merupakan penyakit akut yang paling banyak terjadi pada anak-anak (Wong, 2011). Infeksi Saluran Pernapasan Akut (ISPA) adalah radang akut saluran pernapasan atas maupun bawah yang disebabkan oleh infeksi jasad renik atau bakteri, virus, maupun reketsia tanpa atau disertai dengan radang parenkim paru. ISPA adalah masuknya mikroorganisme (bakteri, virus, riketsi) ke dalam saluran pernapasan yang menimbulkan gejala penyakit yang dapat berlangsung sampai 14 hari. (Price, 2012).

World Health Organization (2017), memperkirakan insidens Infeksi Saluran Pernapasan Akut (ISPA) di negara berkembang dengan angka kematian balita di atas 40 per 1000 kelahiran hidup adalah $15 \%-20 \%$ pertahun pada golongan usia balita. Pada tahun 2010, jumlah kematian pada balita Indonesia sebanyak 151.000 kejadian, dimana $14 \%$ dari kejadian tersebut disebabkan oleh pneumonia.

ISPA merupakan penyakit yang banyak terjadi di negara berkembang serta salah satu penyebab kunjungan pasien ke Puskesmas (40\%-60\%) dan rumah sakit (15\%-30\%). Kasus ISPA terbanyak terjadi di India 43 juta kasus, China 21 kasus, Pakistan 10 juta kasus dan Bangladesh, Indonesia, Nigeria masing-masing 6 juta kasus. Semua kasus ISPA yang terjadi di masyarakat, 7-13\% merupakan kasus berat dan memerlukan perawatan rumah sakit (Dirjen PP \& PL, 2015).

Period prevalence ISPA dihitung dalam kurun waktu 1 bulan terakhir. Lima provinsi dengan ISPA tertinggi adalah Nusa Tenggara Timur $(41,7 \%)$, Papua $(31,1 \%)$, Aceh $(30,0 \%)$, Nusa Tenggara Barat $(28,3 \%)$, dan Jawa Timur $(28,3 \%)$. Period prevalence ISPA Indonesia menurut Riskesdas 2018, (25,0\%). Karakteristik penduduk dengan ISPA yang tertinggi terjadi pada kelompok umur 1-4 tahun $(25,8 \%)$. Menurut jenis kelamin, tidak berbeda antara laki- laki dan perempuan. Penyakit ini lebih banyak dialami pada kelompok penduduk dengan kuintil indeks kepemilikan terbawah dan menengah bawah (Kemenkes RI, 2018).

Kasus ISPA di Indonesia pada tiga tahun terakhir menempati urutan pertama penyebab kematian bayi yaitu sebesar 24,46\% (2015), 29,47\% (2014) dan 63,45\% (2016). Selain itu, penyakit ISPA juga sering berada pada daftar 10 penyakit terbanyak di rumah sakit (Kemenkes RI, 2017). Terdapat lima Provinsi dengan ISPA tertinggi yaitu Nusa Tenggara Timur $(41,7 \%)$, Papua $(31,1 \%)$, Aceh $(30,0 \%)$, Nusa Tenggara Barat $(28,3 \%)$, dan Jawa Timur $(28,3 \%)$. Karakteristik penduduk dengan ISPA yang tertinggi berdasarkan umur terjadi pada kelompok umur 1 - 4 tahun $(25,8 \%)$. Penyakit ini lebih banyak dialami pada kelompok penduduk kondisi ekonomi menengah ke bawah (Kemenkes, 2017).

Di Provinsi Lampung memiliki sepuluh besar penyakit terbesar pertama diduduki oleh penyakit infeksi akut pernafasan bagian atas, tahun 2015 sebesar 27,24\%, tahun 2016 sebesar 29,88\%, tahun 2017sebesar 46,29\%. (Dinas Kesehatan Prov. Lampung, 2012) . ISPA merupakan penyakit saluran atas yang 
banyak diderita oleh masyarakat di Provinsi Lampung (18,8\%), diikuti pneumonia $(0,8 \%)$, campak $(0,4 \%)$, dan TB $(0,3 \%)$. Berdasarkan hasil diagnosis tenaga kesehatan, ISPA paling banyak ditemukan di Lampung Selatan yaitu 13,1\%. Sebanyak $14,4 \%$ penderita ISPA pada usia 0 - 5 tahun, (Riskesdas Lampung, 2018).

Penyakit ISPA sering terjadi pada anak Balita, karena sistem pertahanan tubuh anak masih rendah. Kejadian batuk pilek pada balita di Indonesia diperkirakan 3 sampai 6 kali pertahun, yang berarti seorang balita rata-rata mendapat serangan batuk-pilek 3 sampai 6 kali setahun. Penyakit ISPA dapat ditularkan melalui air ludah, bersin, udara pernapasan yang mengandung kuman yang terhirup oleh orang sehat kesaluran pernapasannya. Infeksi saluran pernapasan bagian atas terutama yang disebabkan oleh virus, sering terjadi pada semua golongan umur, tetapi ISPA yang berlanjut menjadi Pneumonia sering terjadi pada anak kecil terutama apabila terdapat giz i kurang dan dikombinasi dengan keadaan lingkungan yang tidak hygiene (Wong, 2011).

Berbagai faktor risiko yang meningkatkan kejadian, beratnya penyakit dan kematian karena ISPA, yaitu status gizi (gizi kurang dan gizi buruk memperbesar risiko), pemberian ASI (ASI eksklusif mengurangi risiko), suplementasi vitamin A (mengurangi risiko), suplementasi zinc (mengurangi risiko), bayi berat badan lahir rendah (meningkatkan risiko), vaksinasi (mengurangi risiko), dan polusi udara dalam kamar terutama asap rokok dan asap bakaran dari dapur (meningkatkan risiko) (Kartika, 2017).

Strategi untuk pengobatan, pencegahan dan melindungi anak dari ISPA adalah dengan memperbaiki manajemen kasus pada semua tingkatan, vaksinasi, pencegahan dan manajemen infeksi HIV, dan memperbaiki gizi anak. Pemberian antibiotika segera pada anak yang terinfeksi pneumonia dapat mencegah kematian. UNICEF dan WHO telah mengembangkan pedoman untuk diagnosis dan pengobatan pneumonia di komunitas untuk negara berkembang yang telah terbukti baik, dapat diterima dan tepat sasaran. Antibiotika yang dianjurkan diberikan untuk pengobatan pneumonia di negara berkembang adalah kotrimoksasol dan amoksisilin. (Kemenkes RI, 2013).

Dalam mengatasi ISPA khususnya ISPA yang menyerang saluran pernapasan bagian atas seperti batuk, dermam, pilek masyarakat memilih untuk menggunakan atau menyertai terapi lain selain terapi konvensional, yaitu terapi komplementer. Saat ini banyak masyarakat yang menggunakan obat herbal atau terapi relaksasi dalam mengatasi ISPA seperti mengonsumsi jeruk nipis yang dicampur dengan Madu yang dipercaya dapat melegakan tenggorokan dan mengurangi batuk. Ada juga yang melakukan terapi teknik napas dalam sebagai pereda sesak napas, serta beberapa teknik dan ramuan herbal lainnya yang dipercaya dapat mengatasi ISPA (Tersania, 2016)

Peran orang tua antara lain adalah : peran sebagai penyedia, perawatan anak, sosialisasi anak, peran pendidikan, dan peran afektif. Alasan mengapa orang tua memegang peranan penting bagi kesehatan anak karena kehidupan seorang anak ditentukan oleh lingkungan keluarga (Stela, 2016).

Menurut penelitian Nugraheny (2016) sebagai langkah awal untuk menanggulangi batuk pada balita yaitu dengan memberikan obat batuk yang aman yaitu dengan memberikan ramuan tradisional seperti jeruk nipis $1 / 2$ sendok teh dicampur dengan kecap atau madu $1 / 2$ sendok teh yang diberikan tiga kali sehari. Sebagian besar responden telah mengerti terhadap pemberian nutrisi yang baik untuk balitanya dengan memberikan makanan bergizi dan lunak pada saat balita sakit, dan tidak memberi makanan jajanan sembarangan seperti ciki- 
ciki, ice cream, kembang gula pada saat balita sakit. Balita dengan gizi yang kurang akan lebih mudah terserang ISPA dibandingkan balita dengan gizi normal karena faktor daya tahan tubuh yang kurang

Dianjurkan memberi obat batuk yang aman yaitu ramuan tradisional yaitu jeruk nipis $1 / 2$ sendok teh dicampur dengan Madu atau Madu $1 / 2$ sendok teh, diberikan tiga kali sehari. Air perasan jeruk nipis dicampur dengan Madu manis juga menjadi pilihan masyarakat dalam meredakan batuk dan melegakan tenggorokan. Pilihan ini juga telah tercantum di dalam MTBS (Manajemen Terpadu Balita Sakit) dalam mengajari ibu cara mengobati infeksi lokal di rumah. Caranya adalah dengan memotong satu buah jeruk nipis, peras airnya, taruh dalam gelas/cangkir. Tambahkan Madu manis, aduk. Takaran minum untuk anak, 3 kali sendok teh per hari. Cara lain, Madu manis bisa digantikan dengan Madu murni (Rasmaliah,2004) dalam (Tersania, 2016)

\section{MASALAH}

mengatasi ISPA khususnya ISPA yang menyerang saluran pernapasan bagian atas seperti batuk, dermam, pilek masyarakat memilih untuk menggunakan atau menyertai terapi lain selain terapi konvensional, yaitu terapi komplementer. ramuan tradisional yaitu jeruk nipis $1 / 2$ sendok teh dicampur dengan Madu atau Madu $1 / 2$ sendok teh, diberikan tiga kali sehari. Air perasan jeruk nipis dicampur dengan Madu manis juga menjadi pilihan masyarakat dalam meredakan batuk dan melegakan tenggorokan.maka penulis ingin memberikan pendidikan kesehatan cara Keperawatan Bersihan Jalan Nafas Tidak Efektif Dengan Menggunakan Larutan Jeruk Nipis Dan Madu Di Kelurahan Sukabumi Bandar Lampung.

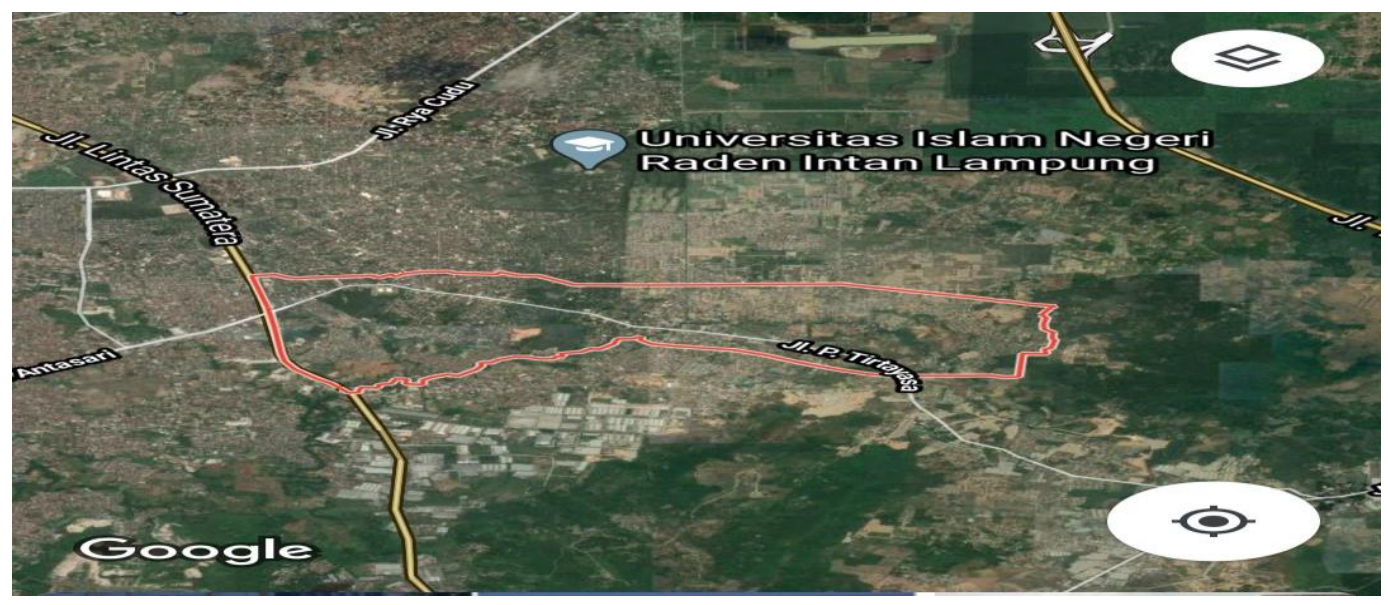

Gambar 2.1 MAP lokasi kegiatan

\section{METODE}

Tindakan untuk mengeluarkan sekret yang terakumulasi dan mengganggu di saluran nafas bagian bawah.

Tahap awal :

Melakukan pengecekan bersihan jalan nafas sebelum intervensi, Menyiapkan alat dan bahan 
Tahap Kerja :

Mencuci Tangan, Potong 1 buah jeruk nipis, peras airnya, taruh dalam gelas / cangkir, Tambahkan Madu manis, aduk. Takaran minum untuk anak, 3 kali 1 sendok teh per hari, Penelitian di lakukan selama 3 hari (Rahmawati, 2017).

Dianjurkan memberi obat batuk yang aman yaitu ramuan tradisional yaitu jeruk nipis $1 / 2$ sendok teh dicampur dengan Madu atau Madu $1 / 2$ sendok teh, diberikan tiga kali sehari. Tambahkan Madu manis, aduk. Takaran minum untuk anak, 3 kali sendok teh per hari

\section{HASIL DAN PEMBAHASAN}

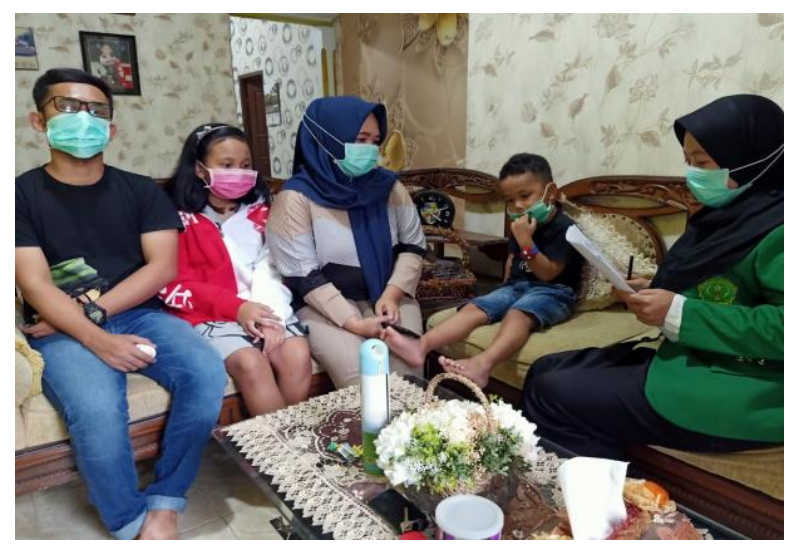

Hasil pengkajian didapatkan keluarga Tn.S tinggal serumah hanya dengan istri, dengan hasil penjajakan tahap 1 dengan masalah anak dengan ketidak efektifan bersihan jalan nafas, Hasil pemeriksaan fisik pada keluarga dengan ISPA didapatkan hasil data subjektif : menegeluh batuk, pilek, dan tidak bisa tidur, anak rewel dan terdapat penumpukan secret pada anak.

Berdasarkan hasil pengkajian yang di dapatkan dari 2 keluarga tersebut di dapatkan diagnose Ketidakefektifan manajemen kesehatan dikeluarga berhubungan dengan Ketidakefektifan manajemen kesehatan dikeluarga berhubungan dengan Ketidakmampuan keluarga merawat anggota keluarganya terhadap gangguan nyaman penderita ISPA Dengan Ketidakefektifan jalan nafas.

Gangguan pola tidur berhubungan dengan ketidakmampuan Mengambil keputusan untuk melakukan tindakan yang tepat Gangguan kebutuhan nutrisi berhubungan dengan Ketidakmampuan Mengenal gangguan perkembangan kesehatan setiap anggotanya.

Diagnosa keperawatan di ambil berdasarkan perhitungan prioritas masalah , sesuai keluhan dan cara mengatasi serta melihat suatu masalah yang harus lebih dulu di tangani, maka penulis mendapatkan diagnose prioritas berdasarkan hasil pengkajian yakni Ketidakmampuan keluarga merawat anggota keluarganya terhadap gangguan nyaman penderita ISPA Dengan Ketidakefektifan jalan nafas

Dianjurkan memberi obat batuk yang aman yaitu ramuan tradisional yaitu jeruk nipis $1 / 2$ sendok teh dicampur dengan Madu atau Madu $1 / 2$ sendok teh, diberikan tiga kali sehari. Air perasan jeruk nipis dicampur dengan Madu manis juga menjadi pilihan masyarakat dalam meredakan batuk dan 
melegakan tenggorokan. Pilihan ini juga telah tercantum di dalam MTBS (Manajemen Terpadu Balita Sakit) dalam mengajari ibu cara mengobati infeksi lokal di rumah. Caranya adalah dengan memotong satu buah jeruk nipis, peras airnya, taruh dalam gelas/cangkir. Tambahkan Madu manis, aduk. Takaran minum untuk anak, 3 kali sendok teh per hari. Cara lain, Madu manis bisa digantikan dengan Madu murni

Setelah dilakukan intervensi sesuai dengan anjuran dokter dan pemberian terapo nonfarmokologi berupa jeruk nipis dan madu pada anak sebagai salah satu terapi melegakan tenggorokan dan mengurangi batuk, ternyata terlihat adaya perbedaan waktu pemulihan diantara kedua pasien tersebut. Pada pasien pertama yakni An.D usia 6 tahun dengan proses penyembuhan membutuhkan waktu 3 hari di rumah, dan porsi batuk berkurang setelah 3 hari, dan pada pasien kedua yakni AN. A usia 10 tahun dengan proses penyembuhan membutuhkan waktu 2 hari dengan porsi batuk berkurang terlihat setelah diberikan terapi jeruk nipis dan madu

Hasil kajian asuhan keperawatan komprehensif pada anak dengan ISPA yang telah dilakukan didapatkan hasil bahwa terjadi perbedaan waktu proses penyembuhan dengan terapi Jeruk nipis madu antara pasien pertama dan kedua hal ini dapat terjadi dikarenakan daya tahan tubuh anak, dan keteraturan dalam mengikuti terapi Jeruk nipis madu.

\section{KESIMPULAN DAN SARAN}

\section{Kesimpulan}

Pelaksanaan pada pengelolaan kasus cemas pada psien ISPA harus selalu disesuaikan dengan kondisi dan keluhan, dan lingkungan, serta kemampuan, dengan melibatkan peran perawat sehingga tujuan dapat tercapai dengan baik. Evaluasi pada Keluarga dengan masalah ISPA teratasi dengan Jaruk nipis dan madu dengan hasil efektif pada kedua pasien hanya saja kadar penurunan penumpukan secret, penurunan batuk dan waktu tidur lebih baik

\section{Saran}

1) Bagi Lahan Praktik

Sebaiknya kerjasama antar perawat dan Keluarga lebih ditingkatkan dan meningkatkan kinerja petugas kesehatan dalam memberikan pelayanan kesehatan kepada penerima manfaat yang membutuhkan informasi masalah kesehatan yang dialami, serta dalam pemberian pelayanan kepada Keluarga disiapkan fasilitas-fasilitas yang memadai untuk menunjang pemeriksaan atau tindakan keperawatan terutama ISPA .

2) Bagi Istitusi

Institusi akademik diharapkan agar terus mengembangkan dan menambahkan referensi buku untuk para mahasiswanya tentang ISPA dan terapi komplementer pada kasus sehingga dapat mempermudah bagi penulis atau peneliti selanjutnya untuk mendapat sumber-sumber referensi buku dan mengembangkan ilmu pengetahuan.

3) Bagi Keluarga dan Masyarakat

Diharapkan dapat meningkatkan pengetahuan dan wawasan tentang bagaimana cara pencegahan penyakit seperti pola hidup yang baik dan lingkungan sekitar yang mendukung sehingga dapat menurunkan angka 
penderita penyakit, khususnya ISPA Serta menerapkan anjuran-anjuran pendidikan kesehatan yang diberikan tenaga kesehatan dalam terapi atau bagaimana penanganan pada suatu penyakit khususnya ISPA Diharapkan keluarga dan masyarakat mencoba melakukan Jaruk nipis dan madu dalam mengurangi Ketidak efektifan jalan nafas pada ISPA secara mandiri dirumah.

\section{DAFTAR PUSTAKA}

Aini, N. N. (2016). Penggunaan Minuman Herbal Jeruk nipis Madu Untuk Kenyamanan Dan Kenyenyakan Tidur An. N Umur 4 Tahun 4 Bulan Selama Mengalami Infeksi Saluran Pernafasan Akut (Ispa) Di Bpm Hariyati Adimulyo Kebumen (Doctoral Dissertation, Stikes Muhammadiyah Gombong).

Kementerian Kesehatan RI. (2013). Pedoman Pengendalian Infeksi Saluran Pernapasan Akut. Jakarta: Direktorat Jenderal Pengendalian Penyakit dan Penyehatan

Kementerian Kesehatan RI. (2013). Riset Kesehatan Dasar 2013. Jakarta: Badan Penelitian dan Pengembangan Kesehatan.

Kementrian Kesehatan RI. (2012). Profil Data Kesehatan Indonesia. Jakarta: Kementrian Kesehatan RI.

Maula, E. R., \& Rusdiana, T. (2016). Terapi Herbal dan Alternatif pada Flu Ringan atau ISPA non-spesifik. Majalah Farmasetika, 1(2), 7-10.

Noorhidayah, N., Yasmina, A., \& Santi, E. (2016). Terapi Kompres Panas Terhadap Penurunan Tingkat Nyeri Klien Lansia Dengan Nyeri Rematik. Dunia Keperawatan, 1(1), 73-79.

Rahmadhani, A. N. (2014). Efektifitas pemberian minuman Jeruk nipis madu Terhadap keparahan batuk pada anak dengan ispa. Jurnal Online Mahasiswa (JOM) Bidang Ilmu Keperawatan, 1(2), 1-7.

Setyaningrum, R. (2019). Aplikasi Pemberian Minuman Herbal Jeruk nipis Merah Dan Madu Untuk Mengatasi Ketidakefektifan Bersihan Jalan Napas Pada Balita Dengan Ispa (Doctoral dissertation, Skripsi, Universitas Muhammadiyah Magelang). 